http://jmscr.igmpublication.org/home/ ISSN (e)-2347-176x ISSN (p) 2455-0450 crossref DOI: https://dx.doi.org/10.18535/jmscr/v8i4.68

\title{
The Study Proportion of HIV Seropositive Prevalence among Patients with Extra Pulmonary Tubercular Lymphadenitis in Western Rajasthan Indian Population
}

\author{
Authors \\ Dr Mangilal Choudhary ${ }^{1}$, Dr Rekha Sirvi ${ }^{2}$ \\ ${ }^{1}$ Assistant Professor, Central lab Pathology \\ ${ }^{2}$ Assistant Professor, Clinic of ICTC Center \\ Govt. Medical College \& Bangur Hospital Pali (Rajasthan), India
}

\begin{abstract}
Objectives: The rising trend of extra-pulmonary tuberculosis among HIV positive patients, study of the proportion of HIV seropositive among patients with tubercular cervical lymphadenitis, variations in clinical presentation, diagnostic yield of FNAC, microbiological findings and cytomorphological pattern of cervical lymph nodes in HIV positives and negatives gains importance.

Methodology: In all, 110 patients, considered as tubercular cervical lymphadenitis cases, were screened by chest radiography, tuberculin test (MT), fine needle aspiration cytology (FNAC) and smear microscopy for AFB of aspirate lymph nodes. All these patients were also tested for HIV sero positivity by two different ETLISA tests, repeated at least twice.

Results: 85 confirmed tuberculosis patients, 16 (18.8\%) had HIV seropositive, in which 9 of (56.2\%) had demonstrable AFB in FNAC cervical node aspirate; only one HIV negative patient (1.4\%) had positive smear microscopy for AFB. Among the 16 HIV positive patients, typical granuloma and/or caseative necrosis were found in 10 patients (62.5\%) and atypical granuloma with numerous macrophages features were found in the remaining 6 patients $(37.5 \%)$.

Conclusion: The high prevalence of HIV seropositivity (18.8\%) among the 85 tubercular cervical lymphadenitis patients suggests a rising trend of HIV infection in pockets of rural western Rajasthan Indian population. Disseminated tuberculosis and atypical cytomorphological features were found in tubercular lymph nodes in our study suggest an advanced stage of HIV disease in our population group.
\end{abstract}

\section{Introduction}

HIV infection is a major threat in the global resurgence of tuberculosis, especially for tuberculosis control in developing countries. The combination of the two infections has altered the clinical presentation and course of tuberculosis. Tubercular cervical lymphadenitis is being increasingly recognized and diagnosed with the advent of HIV infection. Increased frequency of extra-pulmonary tuberculosis, including cervical lymph nodal involvement, correlates well with advanced HIV disease with low CD4 + lymphocyte counts'. HIV infection has already made strong inroads into the rural Western 
Rajasthan Indian population ${ }^{2}$ and evaluation of extra-pulmonary tuberculosis among HIV infected persons in that setting has a bearing on IV disease there.

The objectives of this study were to determine the proportion of HIV infected among the rural patients with tubercular lymphadenitis, evaluate the variations in clinical presentation and microbiological findings and cytomorphological pattern of tubercular cervical lymph nodes among the HIV positive and negative cases of tubercular lymphadenitis.

\section{Material and Methods}

Patients referred to ICTC Center \& central lab pathology for FNAC, suspected of tubercular lymphadenitis from the Department of Thoracic Medicine or Department of Medicine in Government Bangur Hospital suspected tubercular cervical lymphadenitis, newly diagnosed pulmonary tuberculosis patients with disseminated cervical lymphadenitis and those willing to undergo FNAC of the lymph node were selected. The already treated tuberculosis patients with cervical lymphadenitis and those with nontubercular conditions involving lymph nodes were excluded.

Investigations: All the selected patients were subjected to detailed history taking and clinical examination comprising the following investigations: ELISA test, CD 4 lymphocytes count report with $\mathrm{CBC} \&$ ESR with different methods for HIV suspected patients.

Tuberculin skin (MT) test, sputum smear microscopy for AFB, X-ray chest - PA view, cervical lymph node FNAC, FNAC aspirated material smear examination for AFB \& FNAC aspirated material in CBNAAT/ PCR vial for further confirmation of tuberculosis for tuberculosis suspected patients.

\section{Results}

The 110 study patients, $62(56.4 \%)$ were males and $48(43.6 \%)$ were females, 98 patients $(89.1$ $\%)$ were aged between 16 and 40 years (Table 1). Tubercular lymphadenitis was confirmed in 85 patients (Table 2). The remaining 25 patients had non-reactive hyperplasia, non-specific features, secondaries/ metastatic carcinoma, Hodgkin's lymphoma or suppurative lymphadenitis.

The 85 tubercular cervical lymphadenitis patients, $51(60 \%)$ had other lymph nodes enlarged too. Significantly, 24 patients $(28.2 \%)$ had intrathoracic lymph nodal enlargement (Table 3).

Sixteen $(18.8 \%)$ of 85 patients with tubercular cervical lymphadenitis were HIV positive; 12 were males and 4 were females.

Table 1 Age and Sex distribution of study patients

\begin{tabular}{|l|c|c|c|c|c|c|}
\hline $\begin{array}{l}\text { Age group in } \\
\text { Years }\end{array}$ & $\begin{array}{c}\text { MALE } \\
\text { Patients }\end{array}$ & $\begin{array}{c}\text { Percentage } \\
\text { \% }\end{array}$ & $\begin{array}{c}\text { FEMALE } \\
\text { Patients }\end{array}$ & $\begin{array}{c}\text { Percentage } \\
\%\end{array}$ & $\begin{array}{c}\text { TOTAL } \\
\text { Patients }\end{array}$ & $\begin{array}{c}\text { Percentage } \\
\%\end{array}$ \\
\hline$<20$ Years & 23 & $37.1 \%$ & 18 & $37.5 \%$ & 41 & $37.3 \%$ \\
\hline 21-40 Years & 30 & $48.4 \%$ & 27 & $56.3 \%$ & 57 & $51.8 \%$ \\
\hline 41-60 Years & 07 & $11.3 \%$ & 03 & $6.2 \%$ & 10 & $9.1 \%$ \\
\hline$>60$ Years & 02 & $3.2 \%$ & - & - & 02 & $1.8 \%$ \\
\hline \multicolumn{2}{r|}{ Total } & 100 & 48 & 100 & 110 &
\end{tabular}

\begin{tabular}{|l|l|l|l|}
\hline SEX IN \% & MALE - 56.4\% & FEMALE - 43.6\% & TOTAL - 110 Patients \\
\hline
\end{tabular}

Chest skiagrams were normal in $33(38.8 \%)$ patients, pulmonary tuberculosis was found in 21 patients $(24.7 \%)$, hilar and mediastinal glands were enlarged in $28 \%$ patients. In all, 13 patients $(15.3 \%)$ had AFB in sputum and only 2 of them were HIV seropositives. 
Table 2 FNAC findings of cervical lymph nodes according to FNAC

\begin{tabular}{|l|c|c|}
\hline FNAC/CYTOLOGICAL DIAGNOSIS & NO. OF PATIENTS & \% PERCENTAGE \\
\hline Tubercular lymphadenitis & 85 & $77.3 \%$ \\
\hline Reactive hyperplasia & 09 & $8.3 \%$ \\
\hline Non specific lymphadenitis & 08 & $7.3 \%$ \\
\hline Secondaries/ metastatic & 04 & $3.6 \%$ \\
\hline Lymphoma & 02 & $1.8 \%$ \\
\hline Suppurative lymphadenitis & 02 & $1.8 \%$ \\
\hline
\end{tabular}

Table 3 Distribution pattern of tubercular lymph nodes

\begin{tabular}{|l|c|c|}
\hline SITES OF LYMPHNODES & NO. OF PATIENTS & PERCENTAGE \% \\
\hline CERVICAL & 85 & 100 \\
\hline HILAR / MEDIASTINAL & 24 & 28.2 \\
\hline AXILLARY & 20 & 23.5 \\
\hline INGUINAL & 08 & 9.4 \\
\hline
\end{tabular}

Among the 16 HIV Seropositive, 8 patients (50\%) had hilar and / or mediastinal adenopathy and 5 (31.2\%) had pulmonary tuberculosis lesions (Table 4). Just 2 patients with pleural effusion and one with pericardial effusion were found to have HIV infection. In the HIV negative patients, 33 (47.8\%) had a normal chest skiagram and 16 (23.2\%) had intra-thoracic lymphadenitis.

Table 4 Radiological findings in HIV positive and HIV negative patients

\begin{tabular}{|l|c|c|c|c|c|c|}
\hline $\begin{array}{l}\text { CHEST X RAY } \\
\text { FINDINGS }\end{array}$ & $\begin{array}{c}\text { HIV } \\
\text { POSITIVE } \\
\text { PATIENTS }\end{array}$ & $\begin{array}{c}\text { HIV } \\
\text { POSITIVE } \\
\text { \% }\end{array}$ & $\begin{array}{c}\text { HIV } \\
\text { NEGATIVE } \\
\text { PATIENTS }\end{array}$ & $\begin{array}{c}\text { HIV } \\
\text { NEGATIVE } \\
\text { \% }\end{array}$ & $\begin{array}{c}\text { TOTAL } \\
\text { PATIENTS }\end{array}$ & TOTAL \% \\
\hline NORMAL & 0 & - & 33 & 47.8 & 33 & 38.8 \\
\hline $\begin{array}{l}\text { HILAR/ } \\
\text { MEDIASTINAL } \\
\text { GLANDS }\end{array}$ & 08 & 50 & 16 & 23.2 & 24 & 28.2 \\
\hline $\begin{array}{l}\text { PARENCHYMAL } \\
\text { LESIONS }\end{array}$ & 05 & 31.2 & 16 & 23.2 & 21 & 24.7 \\
\hline BRONCHIECTASIS & - & - & 04 & 5.8 & 04 & 4.7 \\
\hline $\begin{array}{l}\text { PLEURAL } \\
\text { EFFUSIONS }\end{array}$ & 02 & 12.5 & - & - & 02 & 2.4 \\
\hline $\begin{array}{l}\text { PERICARDIAL } \\
\text { EFFUSIONS }\end{array}$ & 01 & 6.3 & - & - & 01 & 1.2 \\
\hline TOTAL & 16 & 100 & 69 & 100 & & 85 \\
\hline
\end{tabular}

\section{Discussion}

Tubercular granuloma and caseation were found in $10(62.5 \%)$ of the $16 \mathrm{HIV}$ seropositives; the remaining $6(37.5 \%)$ had necrotizing atypical granuloma (Table 5). Among the 69 HIV negative patients, 68 (98.6\%) had typical features of tubercular lymphadenitis and one patient had an atypical cytomorphological features. Significantly, 8 FNAC specimens (50\%) of the $16 \mathrm{HIV}$ seropositives had demonstrable AFB compared with one $(1.4 \%)$ in the HIV negative patients; the bacilli seen were beaded shaped slightly curved magenta colored acid fast bacilli seen in sputum smear. 


\section{JMSCR VoI||08||Issue||04||Page 361-366||April}

Cytomorphological MGG stained FNAC images shows different patterns in Tubercular cervical lymphadenitis with HIV Seropositive patients
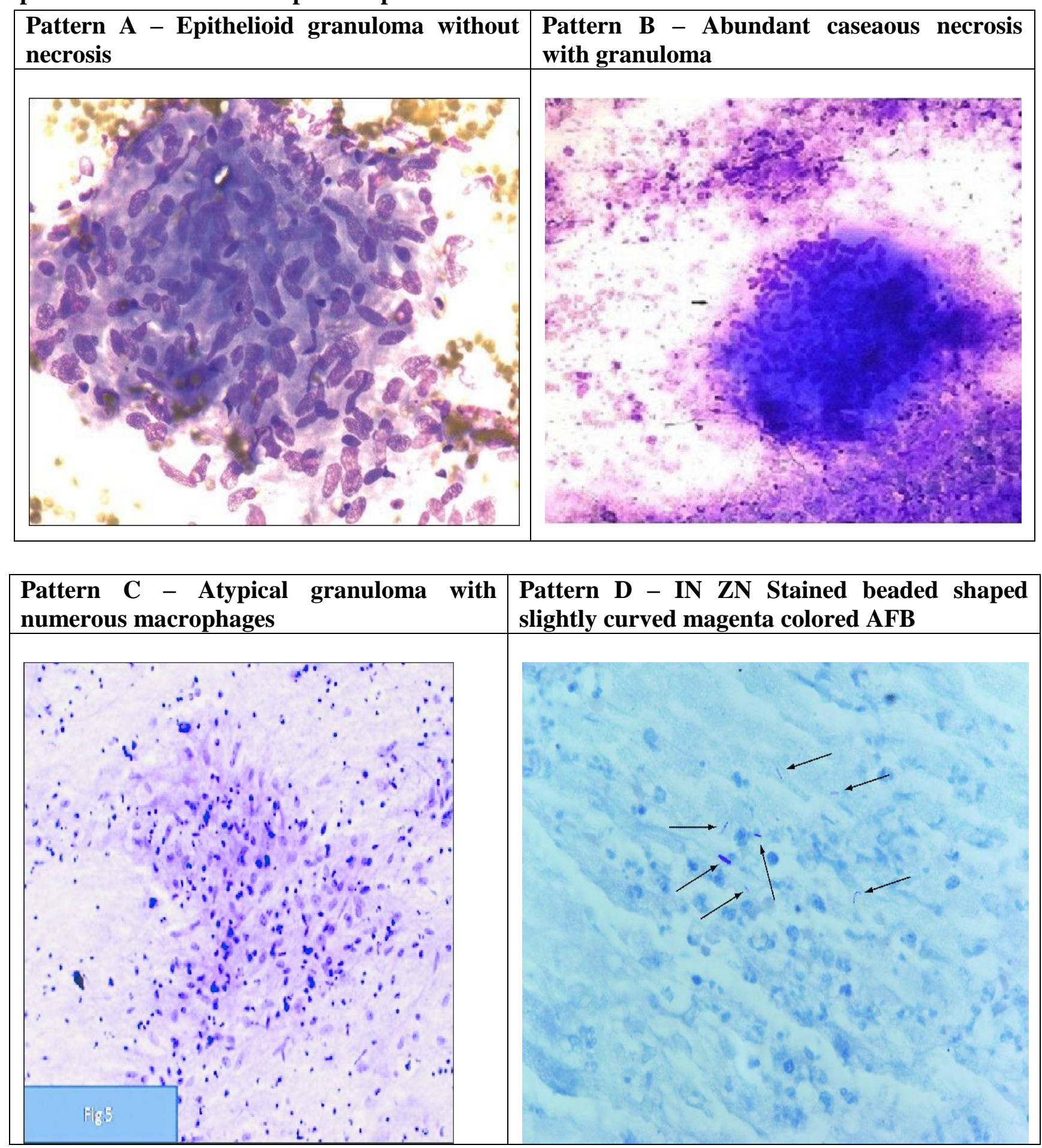

Table 5 Cytomorphological pattern in FNAC of tubercular cervical lymphadenitis in HIV positive and HIV negative patients

\begin{tabular}{|l|c|c|c|c|c|c|}
\hline $\begin{array}{l}\text { CYTOMORPHOLOGICAL } \\
\text { PATTERN }\end{array}$ & $\begin{array}{c}\text { HIV } \\
\text { POSITIVE } \\
\text { PATIENTS }\end{array}$ & $\begin{array}{c}\text { HIV } \\
\text { POSITIVE } \\
\boldsymbol{\%}\end{array}$ & $\begin{array}{c}\text { HIV } \\
\text { NEGATIVE } \\
\text { PATIENTS }\end{array}$ & $\begin{array}{c}\text { HIV } \\
\text { NEGATIVE } \\
\mathbf{\%}\end{array}$ & $\begin{array}{c}\text { TOTAL } \\
\text { PATIENTS }\end{array}$ & $\begin{array}{c}\text { TOTAL } \\
\boldsymbol{\%}\end{array}$ \\
\hline TYPICAL GRANULOMA & 06 & $37.5 \%$ & 56 & $81.2 \%$ & 62 & $73.0 \%$ \\
\hline CASEATION/ NECROSIS & 04 & $25.0 \%$ & 12 & $17.4 \%$ & 16 & $18.8 \%$ \\
\hline $\begin{array}{l}\text { NECROTIZING ATYPICAL } \\
\text { GRANULOMA }\end{array}$ & 06 & $37.5 \%$ & 01 & $1.4 \%$ & 07 & $8.2 \%$ \\
\hline TOTAL & 16 & $100 \%$ & 69 & $100 \%$ & 85 & $100 \%$ \\
\hline
\end{tabular}


Tubercular cervical lymphadenitis is met with predominantly in children and young females. With the advent of HIV epidemic in India, tubercular cervical lymphadenitis is being increasingly observed, especially among the sexually active age groups. The HIV epidemic in central Africa has led to a large increase in diagnostic lymph node biopsies and an increase in HIV related adult tubercular lymphadenitis ${ }^{3}$.

The diagnosis of tubercular lymphadenitis in immuno-competent HIV negative patients depends on the characteristic cytomorphological features in FNAC and identification of AFB in fine needle aspirated specimens. The diagnostic yield of AFB in aspirated specimens was found to be $30 \%$ to $42 \%^{4-7}$. In this study, $\mathbf{5 0 \%}$ of the $\mathbf{1 6}$ HIV seropositives had demonstrable AFB from cervical lymph node specimens and very low yield in HIV negative patients.

There are two specific cytomorphological criteria in FNAC for identifying tubercular lymphadenitis - caseation and granuloma formation. Caseation has been found to be more specific and sensitive ${ }^{8}$ : macroscopic caseation showed a high yield of $82 \%$ in one study 9 .

However, typical granuloma and caseation are less likely to be found in tubercular lymphadenitis in advanced HIV disease because T- cell functions are necessary for epithelioid granuloma formation. In advanced HIV disease, with more severe suppression of CD4 + lymphocytes, no epithelioid cell formation but foamy macrophages were found $^{10}$.

In the present study, typical granuloma formation and caseation were observed in $62.5 \%$ of the HIV seropositives, representing an early phase of immuno-suppression and the remaining $37.5 \%$ patients had atypical necrotising granulomatous features, a pattern consistent with advanced HIV disease. Increased frequency of tubercular lymphadenitis detection by microbiological method would be possible in the presence of necrotizing lymphadenitis ${ }^{11,12}$

The high prevalence of HIV seropositivity $(18.8 \%)$ among the 85 tubercular cervical lymphadenitis patients suggests a rising trend of HIV infection in rural western Rajasthan Indian population. Disseminated tuberculosis and atypical cytomorphological features in FNAC found in tubercular cervical lymph nodes in our study suggest an advanced stage of HIV disease in our population group.

\section{References}

1. Jones BE, Young SM, Antoniskis D, Davidson PT, Kramer F and Barnes PF; Relationship of the manifestations of tuberculosis to CD4 cell counts in patients with human immunodeficiency virus infection; Am Rev Respir D«:1993, 148, 1292

2. Rajasekaran S, Uma A, Kamakshi S, Jeyaganesh D, Senthamizhchelvan A, Savithri S and Gopinathan; Trend of HIV infection in patients with Tuberculosis in rural south India; Ind J Tub ;2000,47,223

3. Bern C, Patil PS, Luo N; The increased burden of tuberculous lymphadenitis in central Africa : Lymph node biopsies in Lusaka, Zambia, 1981 and 1990; Trap Doct; 1996,26,58

4. Malakar D, Jajoo UN, Kiran Swarup, Gupta OP, Jain AP, Poflee VW;A clinical evaluation of Fine Needle Aspiration Cytology in the diagnosis of lymphadenopathy; Ind. J Tub ;1991,38,17

5. Deepjyoti V. Gadre, Usha R. Singh, Kamalcsh Saxena, Arati Bhatia, Vibha Talwar; Diagnosis of tubercular cervical lymphadenitis by FNAC, microscopy and culture; Ind. J. Tub;1991,38,25

6. Narang P, Rahul Narang, Mendiratta DK, Sharma SM, Narang R, Nayar S; Field study to evaluate the bacteriological parameters in the diagnosis of lymphnode tuberculosis in children; Ind $\mathrm{J}$ Tub; 1998,45,211

7. Rajeev Sen, Nisha Marwah, Gupta KB, Sanjay Marwah, Ritu Arora, Jain K; 
Cytomorphologic patterns in tuberculous lymphadenitis; Ind J Tub; 1999,46,125

8. Finfer M, Perchick A, Burstein DE; Fine Needle Aspiration Biopsy diagnosis of tuberculosis lymphadenitis in patients with and without the acquired immunedeficiency syndrome; Acta Cytol; 1991,31,325

9. Bekedam HJ, Boeree M, Kamenya A, Liomba G, Ngwira B, Subramanyam VR, Harries AD; Tuberculous lymphadenitis, a diagnostic problem in areas of high prevalence of $111 \mathrm{~V}$ and tuberculosis; Trans RSoc Trap Med Hyg; 1997,91,294

10. Muller H, Takeshita M.; In situ immunophenotype of macrophages and lymphocytes in granuloma formation of tuberculous lymphadenitis in HIV-infccted and immuno- compctent patients; Res Virol;1991,142,159

11. Parenboom RM, Richter C, Swai AB, Kitinya J, Mtoni I, Chande H, Kazema RR; Clinical features of HIV seropositive and HIV seronegative patients with tuberculous lymphadenitis in Dar es Salaam; Tuber Lung DIS, 1995,76,401

12. Lanjewar DN, Profile of AIDS pathology in India : an autopsy study; Nat Med J Ind; $1996,3,119$. 